\title{
Letting the Cat out of the Bag: EFL College Students' Attitudes towards Learning English Idioms
}

\author{
Shorouq K. Al-Houti ${ }^{1} \&$ Sultan M. Aldaihani ${ }^{1}$ \\ ${ }^{1}$ English Department, College of Basic Education, Kuwait City, Kuwait \\ Correspondence: Shorouq Al-Houti, English Department, Collge of Basic Education, Al-Ardhiya, Block 1, \\ Mohammed Ibn Al-Qasim Street, facing Jaber Stadium, Kuwait City, Kuwait
}

Received: January 13, 2018

Accepted: January 25, 2018

Online Published: January 31, 2018

doi:10.5430/ijhe.v7n1p140

URL: https://doi.org/10.5430/ijhe.v7n1p140

\begin{abstract}
Learning idioms is an uphill battle for many language learners. Thus, this quantitative study aims to shed light on English as Foreign Language (EFL) college students' attitudes towards idiom learning. Specifically, the study is interested in revealing their attitudes towards (1) the importance of idiom learning, (2) the difficulties of idiom learning and (3) the learning strategies of idioms. Additionally, the study attempts to determine if there is an influence of age and/or year of study on the students' attitudes towards learning English idioms. Participants were 218 female EFL college students at the College of Basic Education (CBE) in Kuwait. A five-point Likert-scale questionnaire was employed to obtain data for the study. Data analysis of the questionnaire uncovered the learners' preferred strategies and sources of difficulties when learning idioms. Results showed that students had positive attitudes towards English idiom learning. Significant differences in the results were found when age was taken into account.
\end{abstract}

Keywords: Idiom learning, EFL students, College students' attitudes, Learning strategies, Idiom difficulties

\section{Introduction}

Vocabulary teaching has witnessed a shift from teaching isolated words to teaching language chunks. These language chunks include phrases such as idioms, proverbs and collocations. They are referred to collectively as formulaic sequences, multi-word units or prefabricated units. Formulaic sequences, which cover a wide range of phraseology, are ubiquitous in language use and they make up a large portion of any discourse (Nattinger \& DeCarrico, 1992). They are an important element of language and they contribute to fluency (Nation \& Meara, 2002).

They are one of the essential features of natural language and they are regarded as part of figurative language (Irujo, 1986). Nattinger and DeCarrico (1992) define idioms as "complex bits of frozen syntax, whose meanings cannot be derived from the meaning of their constituents, that is, whose meanings are more than simply the sum of their individual parts" (P.33). In a standard view, an idiom is a multiple word unit whose overall meaning is not merely derived from its individual parts. For this reason and others, idioms are a stumbling block to many second/foreign language learners (Cooper, 1998; Irujo, 1986a; Lattey, 1986; Moon, 1998; Sparado, 2013). According to Glucksberg (2001), mastering idioms is important but difficult task. To turn to attitudes, Gardner (1985) defines attitude as an evaluative reaction to some referent, inferred on the basis of the individual's beliefs and opinions about the referent. Language attitude is an essential concept because it plays an eminent role in language learning and teaching (Dörnyei \& Csizér, 2002; Fakeye, 2010; Gardner \& Lambert, 1972; Kara, 2009; Oller, 1979).

Given the need for language learners to acquire idioms and the difficulties they face in learning these chunks, tackling this aspect is a research-worthy issue. Also, EFL learners' attitudes are significant as they play a vital role in learning and teaching. Unfortunately in the past, idioms were a neglected topic in ESL/EFL contexts (Khan \& Can Daşkin, 2014; Tărcăoanu, 2012; Wray, 2000). Recently; however, idioms are receiving much more attention. Despite this growing interest, research exploring the acquisition of idioms and/or learners' attitudes towards idioms in the Arab world in general and in Kuwaiti EFL context in particular is scant. The Kuwaiti EFL context is a unique socio-cultural background that can provide valuable insights. 


\section{Statement of the Problem}

Despite the extensive use of idioms by native speakers in all form of discourse, they seem to be a neglected topic in ESL/EFL teaching materials (Lazar, 1996; Liu, 2008; Tărcăoanu, 2012). This could be due to the difficulties in characterizing idioms (Cacciari \& Tabossi, 1993). According to Mäntylä (2004), it is impossible to define idiom in an indisputable way. Also, teachers may face difficulties in selecting idioms and creating appropriate teaching methods. Simpson and Mendis (2003) stated that teachers encounter problems in choosing which idioms to teach as native speakers' repertoire of idioms is comprehensive covering wide range of idiomatic expressions.

There are only few studies on idioms in EFL contexts specifically Arabic learners of English. Studies on attitudes of Kuwaiti Arabic leaners' of English when it comes to idiom learning are exceptionally rare or non-existing. Understanding attitudes of Kuwaiti EFL learners towards idiom learning can provide valuable teaching suggestions and approaches. Investigating Kuwaiti EFL learners' attitudes towards the importance of idioms and the difficulties they face can persuade teachers to take on the challenge of teaching idioms. The study will pinpoint the sources of difficulties Kuwaiti students have in learning idioms. Additionally, investigating Kuwaiti EFL learners' attitudes regarding their preferred strategies can guide teachers to develop effective methods for idiom instruction. For a successful teaching of idioms, teachers require to understand the strategies learners utilize to acquire idioms (Tran 2011).

The present study hopes to fill the research gap by investigating Kuwaiti EFL learners' attitudes towards idiom learning, sources of difficulties, and their preferred learning strategies. The study seeks to provide pedagogical contribution in the realm of idiom teaching and learning. The results of this study can motivate language teachers to integrate idioms in their teaching. Also, the study intends to highlight the difficulties language learners face in comprehending and learning English idioms. Moreover, it can pinpoint the strategies language learners utilize to interpret and learn idioms.

\section{Literature Review}

Factors that contribute to the importance of idioms, the sources of difficulties as well as learning strategies are discussed in this section.

\subsection{Importance of Idioms}

Idioms are important in ESL/EFL contexts. Researchers stressed the importance of idioms for a successful communication in both academic and non-academic contexts (Dixon, 1994; Lundblom \& Woods, 2012). According to Fernando, "No translator or language teacher can afford to ignore idioms or idiomaticity if a natural use of the target language is an aim" (1996: 234).

The first reason for the paramount importance of idioms is that they are pervasive (Bortfeld, 2003). Elkilic (2008) mentioned that English is abundant with idioms and learning them constitutes the soul of the language. Native speakers use idioms frequently and they find it hard to speak or write without such expressions (Seidl \& McMordie, 1978). According to Makkai, "There are, in fact, no known languages that do not have some idioms" (1978, p.83). Pollio et al. (as cited in Cooper, 1999) estimated that "most English speakers utter about 10 million novel metaphors per lifetime and 20 million idioms per lifetime, and this works out to about 3,000 novel metaphors per week and 7,000 idioms per week" (p.233). Since English idioms are commonly used in a myriad of daily situations, they must form an integral part of the syllabus for EFL classroom.

Other than frequency, idioms incorporate cultural aspects (Bachman, 1990). They are institutionalised i.e. specific to culture or language. Knowledge of idioms is considered to be a vital sign of communicative competence and intercultural awareness (Boers, Eyckmans \& Demecheleer, 2004; Celce-Murcia, 2008; Ellis, 1997; Kovecses \& Szabo, 1996; Littlemore \& Low 2006). Idioms help in broadening learner's knowledge of the culture and history of a language. Mastery of a language is incomplete without an understanding of the culture of that language. Taking this into account, idioms are vital to attain mastery of a foreign language.

Another reason for importance of idioms comes from the fact that they indicate proficiency. Non-natives that utilize formulaic language in spoken and written discourse are judged as more proficient (Boers, Eyckmans, Kappel, Stengers \& Demecheleer, 2006; Ohlrogge, 2009). In addition, many researchers consider mastering a wide range of idioms to be an indication of native-like command of the language (Clarke \& Nation, 1980; Cowie \& Mackin, 1975; Fernando, 1996; Schmitt, 2000; Wray, 2000). Therefore, idiomatic expressions are used to assess the learners' language proficiency. Absence of idiomatic competence classifies the leaner as a member of the foreigner camp (Bulut \& Çelik -Yazici, 2004). 
Finally, idiomatic expressions reflect a figurative sense, which adds a special effect or imaginative descriptions. These expressions are important because they give language a peculiar flavour and colour. All in all, using idioms is important for EFL/ESL learners and including idioms in education is needed (Foster, 2001; Howarth, 1998; Nattinger \& DeCarrico, 1992; Wray, 2002). In addition, it is essential for students to be aware of the importance of learning idioms and to recognise the need of including idioms in language programs.

\subsection{Difficulties of Idiom Learning}

Idioms present a host of difficulties to English language learners and they are widely recognized as a stumbling block. Prior research suggested that idioms are difficult for L1 learners (e.g. Gibbs, 1994; Nippold, 1991), language-disordered learners (e.g. Nippold \& Fey, 1983; Nippold, 1991), and ESL/EFL learners (e.g. Adkins, 1968; Cedar, 2008; Cooper, 1999; Irujo, 1986). The difficulty of idioms can stem from the fact that they are deeply rooted in the culture of the target language. These cultural-specific expressions require knowledge of the culture of the target language in order to minimize the difficulty of learning them. According to Pimenova (2011), the difficulty of learning idioms is attributed to cultural differences, lack of analog idioms in L1 and other challenges. From another dimension, Cooper (1999) stated that idioms are difficult for language learners because the figurative meaning can be unpredictable. Learners are required to go beyond word-by-word interpretation and they must resort to figurative meaning. For example, once in a blue moon means rare occurrences. Idioms are categorised on a continuum from transparent to opaque or decomposable to non-decomposable. Transparent/ decomposable idioms are easy to comprehend due to clear relationship between the individual lexical components and the figurative meaning (Cooper, 1998; Gibbs, 1993). Gibbs (1993) considered the idiom to button (up) one's lip, for instance, as decomposable by virtue of the visible connection between the figurative meaning of to stop talking and the literal reading of the phrase. Hence, such idioms are unlikely to cause interpretation difficulties for L2 learners. On the other hand, a non-decomposable idiom like to kick the bucket with idiomatic meaning to die, is acknowledged to be bewildering for L2 learners due to unrelated literal and nonliteral meanings.

In the same vein, Irujo (1986b) discussed the difficulties involved in learning idioms. According to Irujo (1986b), non-literalness is among the reasons why idioms are difficult to learn in a second language. Language learners are faced with difficulties in figuring out the non-literal meaning of idioms. The second factor that contributes to the difficulties involved in learning idioms is exposure to idioms (Irujo, 1986b). She highlighted the fact that idioms are generally omitted in the speech addressed to L2 learners. Hence, there is lack of exposure to idioms. Thirdly, idioms are difficult to use correctly (Irujo, 1986b). Idioms have grammatical constraints and they must be employed in appropriate situations. For example, make head or tail of, is an idiom that is used in the negative as in he can't make head or tail of this. Some idioms are flexible idioms that tolerate grammatical transformations; however, most idioms are frozen/fixed that do not tolerate changes. For instance, it is impermissible to passivize the idiom kick the bucket while maintaining the idiomatic meaning. Furthermore, Irujo (1986a) pointed out that idioms that are present in the leaner's first language are easy to learn. There are many identical idioms particularly if the languages are related. Positive transfer can be utilized with identical idioms. Similar, but not identical, idioms can be problematic for learners (Irujo, 1986a). They can lead to interference or negative transfer. Different idioms are also difficult for leaners. Finally, Irujo, (1986b) pointed out to the lack of sufficient teaching materials as idioms are often ignored. Researchers agreed that idioms seem to be a neglected topic in ESL/EFL teaching materials (Khan \& Can Daşkin, 2014; Tărcăoanu, 2012; Wray, 2000). Recently; however, teaching idioms received much more attention.

\subsection{Comprehension Strategies}

A number of studies investigated comprehension strategies employed by learners to decode idioms (Chen, 2004; Cooper, 1999; Zuo, 2008). Studies revealed the effectiveness of relying on contextual clues as a strategy to guess the meaning of idioms (Bulut \& Celik-Yazici, 2004; Cooper, 1999; Zyzik, 2009). According to Cooper (1999), learners employed eight major comprehension strategies including referring to L1 to decode idioms. Copper (1999) demonstrated that guessing from context was the most frequently used strategy. Along the same line, Liu (2008) presented the main strategies learners utilize to understand idioms in another language. These strategies according to Liu (2008) include use of contextual knowledge and use of L1. Additionally, Guduru (2012) presented useful methods for learning/teaching idioms including the keyword method. Research on the effect of etymological elaboration on idiom acquisition has showed that, it is a useful mnemonic approach, which can aid language learners retain target idioms (Boers, Demecheleer, Eyckmans, 2004). This technique can enhance learner's motivation to learn as it arouses learner's curiosity. However, not all experimental data indicated a positive effect of etymological information. Szczepaniak and Lew (2011) showed that pictorial support had a significantly stronger mnemonic effect than the presence of etymological notes. Some researchers examined the role of L1 as a strategy to comprehend and 
learn idioms (Irujo, 1986a; Pimenova, 2011). Relying on L1 as a strategy may assist language learners but it can also lead to interference (Irujo, 1986a). Saleh and Zakaria (2013) explored the difficulties Libyan students face in comprehending idioms and the strategies they utilize to improve comprehension. The findings revealed that the most effective strategy was guessing from context followed by referring to L1. There are many studies that focused on Chinese EFL leaners and idiom comprehension. These studies revealed that idiom types and Learners' L2 proficiency had an influence on idiom comprehension and strategy use (Chen, 2004; Zuo, 2008). Learners employed several strategies with difficult idioms. Also, advanced learners adopted more strategies than other learners to comprehend unfamiliar idioms.

\subsection{Idiom Learning Attitudes in L2 Contexts}

Attitudes, whether positive, natural or negative, determine the ease or difficulty of learning. Thus, positive attitude plays a key role in language learning. According to Oller (1979), attitudes give rise to motivation, which ultimately results in attainment of proficiency in a second language. Similarly, Kara (2009) stated that attitudes play an important role in directing students' behaviours and consequently their performance. Moreover, Dörnyei and Csizér (2002) stated that positive attitude facilitates EFL learning whereas negative attitude acts as a psychological barrier against learning.

L2 learners have a strong desire to master idioms to sound "natural" and non-foreign (Richards, 1996: 32). According to Thiel (1979), "sooner or later, lack of precise idiomatic usage will betray the foreign background even of a speaker with an excellent grammatical knowledge, vocabulary, and pronunciation" (p.23). Liu (2008) showed that learners that had great exposure to the target language understand more the value of idioms. In addition, Liu (2008) highlighted the eagerness of many learners to learn idioms.

Driven by the difficulties students have in learning idioms as well as he importance of idioms and attitudes, the purpose of this questionnaire-based quantitative study is to examine students' attitudes towards idiom learning. Specifically, the study aims to solicit Kuwaiti EFL undergraduate college students' attitudes towards (1) the importance of idiom learning, (2) the difficulties of idiom learning and (3) the learning strategies of idioms. The study aims to find out whether the students' attitudes are linked to age and year of study. These factors can cause an effect on attitude. The research questions posed by this study are:

1. What are the EFL college students' attitudes towards learning English idioms?

a. What are the EFL college students' attitudes towards the importance of English idiom learning?

b. What are the EFL college students' attitudes towards the difficulties of English idiom learning?

c. What are the EFL college students' attitudes towards learning strategies of idioms?

2. Do EFL college students' attitudes differ according to age?

3. Do EFL college students' attitudes differ according to year of study?

\section{Method}

\subsection{Participants}

The participants of the study were 218 female EFL undergraduate students studying at the CBE (College of Basic Education) in Kuwait. Their age range was between 18-41, 18-24 (72.5\%) and 25-41 (27.5\%). Table 1 shows the demographics of the participants.

Table 1. Distribution of Sample

\begin{tabular}{cccc}
\hline Independent Variables & & No. & $\%$ \\
\hline Age & Less than 25 & 158 & 72.5 \\
& 25 and more & 60 & 27.5 \\
& Total & 218 & 100 \\
Year of Study & Second & 8 & 3.7 \\
& Third & 44 & 20.2 \\
& Fourth & 91 & 41.7 \\
& Fifth & 38 & 17.4 \\
& Total & 181 & 100 \\
\hline
\end{tabular}

Note: $\mathrm{N}=218.37$ missing values for "year of study". 


\subsection{Instrument}

A questionnaire was devised to measure students' attitudes towards learning English idioms (Table 2). The questionnaire items were created after a thorough examination of the relevant literature (see e.g. Cooper, 1999; Guduru, 2012; Irujo 1986; Khan \& Can Daşkin, 2014; Liu, 2008; Pimenova, 2011; Saleh \& Zakaria, 2013; Tran, 2013). The questionnaire consisted of 19 items with a five-point Likert scale ( $1=$ strongly disagree, $2=$ disagree, $3=$ neutral, $4=$ agree, and $5=$ strongly agree).

The 19 items consisted of three sub-scales of students' attitudes towards learning English idioms:

1. Attitudes towards importance of English idiom learning (8 items: Q1-Q8),

2. Attitudes towards difficulties of English idiom learning (6 items: Q9-Q14), and

3. Attitudes towards learning strategies of idioms (5 items: Q15-Q19).

\subsection{Procedure}

The questionnaire was piloted with a small group of EFL undergraduate students at CBE to check clarity of the items before the actual implementation as well as to verify the reliability and validity of the instrument. As a result, some modifications were made to enhance the questionnaire. The modifications mainly involved incorporating additional statements. The pilot study results were not included in the main study. The revised version of the questionnaire was distributed during the academic year 2016-2017 at the CBE. A Cronbach's alpha was above .70, suggesting that reliability of the instrument was satisfactory. All subjects gave informed consent to participate in the study and ethical approval was obtained.

\section{Data Analysis}

The questionnaire items contained 3 sub-scales of students' attitudes towards learning English idioms. For each subscale, a composite score was created, by averaging the responses of the corresponding survey items. The composite scores ranged from 1 to 5 , with higher scores indicated more positive attitudes towards the sub-scale.

Frequency tables and descriptive statistics were used to summarize the survey responses for each individual item and the 3 sub-scales of EFL college students' attitudes towards learning English idioms. Normality of the data was assessed via the Shapiro-Wilk tests. A p-value $<0.05$ of the Shapiro-Wilk test indicated that data were not normally distributed. Kruskal-Wallis tests (Hollander and Wolfe, 1999) were used to determine if there was a statistically significant difference in the 1) 3 sub-scales of EFL college students' attitudes towards learning English idioms, and 2) the responses of each individual survey item, among participants with different year of study. If the results of Kruskal-Wallis test were significant, Dunn's procedure (Dunn, 1964) for pairwise comparisons was performed. Additionally, Wilcoxon ranked-sum tests (Hollander and Wolfe, 1999) were used to determine if there was a statistically significant difference in the 1) 3 sub-scales of EFL college students' attitudes towards learning English idioms, and 2) the responses of each individual survey item, between the two age groups. For all tests, p-values less than 0.05 , indicated significance. All analyses were conducted using SPSS version 23 (IBM Corp., Armonk, NY).

\section{Results and Discussion}

\subsection{First Research Question}

The first research question asked: What are the EFL college students' attitudes towards learning English idioms? Table 2 shows the summary statistics of the sub-scales of EFL college students' attitudes towards learning English idioms. The results suggested that participants had strongly positive attitudes towards importance of English idiom learning $(\mathrm{M}=4.06, \mathrm{SD}=0.50)$, moderately positive attitudes towards difficulties of English idiom learning $(\mathrm{M}=$ $3.26, \mathrm{SD}=0.74)$, and moderately positive attitudes towards learning strategies of idioms $(\mathrm{M}=3.55, \mathrm{SD}=0.59)$.

Table 2. Summary statistics of the sub-scales of EFL college students' attitudes towards learning English idioms

\begin{tabular}{lllll}
\hline & Mean (SD) & Median & Min & Max \\
\hline Attitudes towards importance of English idiom learning & $4.06(0.50)$ & 4.13 & 2.25 & 5.00 \\
Attitudes towards difficulties of English idiom learning & $3.26(0.74)$ & 3.33 & 1.17 & 5.00 \\
Attitudes towards learning strategies of idioms & $3.55(0.59)$ & 3.60 & 1.60 & 4.80 \\
\hline
\end{tabular}

Note: $\mathrm{N}=218 . \mathrm{SD}=$ standard deviation 


\subsubsection{Importance of Idioms}

The findings in general indicated that students have strongly positive attitudes towards the importance of English idiom learning. The statements for this sub-scale as well as means and standard deviations are displayed in Table 3.

Table 3. Means and standard deviations for EFL college students' attitudes towards the importance of idiom learning

\begin{tabular}{llll}
\hline No. & Statement & \% Agree & Mean (SD) \\
\hline Q1 & Idioms are very important for English language learners. & 86.7 & $4.22(0.74)$ \\
Q2 & English language learners should have knowledge about idioms & 93.1 & $4.40(0.70)$ \\
Q3 & English language teachers should teach students idioms & 72.9 & $3.95(0.84)$ \\
Q4 & Idioms should be included in language curricula & 56.0 & $3.60(0.95)$ \\
Q5 & Idioms are important because they are frequent and common & 83.0 & $4.07(0.76)$ \\
Q6 & Idioms are important because they can communicate aspects in a & 84.4 & $4.24(0.79)$ \\
& nonliteral (figurative) way & & $3.97(0.95)$ \\
Q7 & Idioms are important because they reflect and represent culture & 75.2 & $4.02(0.93)$ \\
Q8 & $\begin{array}{l}\text { Idioms are important because they indicate native-like knowledge of } \\
\text { the language as they reflect proficiency }\end{array}$ & 74.7 & \\
\hline
\end{tabular}

Note: $\mathrm{N}=218 . \%$ Agree $=\%$ of participants choosing agree or strongly agree. $\mathrm{SD}=$ standard deviation

The majority of the participants responded with "agree" $(106,48.6 \%)$ or "strongly agree" $(83,38.1 \%)$ to statement 1 . Also, the majority believed that learners should have knowledge about idioms (\% agree =93.1). Similarly, Liu (2008) highlighted the eagerness of many learners to gain knowledge about idioms. Regarding the importance of teaching idioms, the majority of students responded with "agree" $(99,45.4 \%)$ or "strongly agree" $(60,27.5 \%)$. Only slightly over half of the participants agreed that idioms should be included in language curricula $(\%$ agree $=56.0 \%)$. The finding showed that many students seem to lack awareness about the importance of including idioms in the syllabus for EFL classroom. Over $70 \%$ of the participants agreed to statements 5, 6, 7 and 8 . Thus, students were aware of the importance of idioms and its link to frequency and figurativeness. In addition, students were aware that idioms are important because they incorporate cultural aspects and they reflect proficiency.

\subsubsection{Difficulties of Idiom Learning}

Regarding attitudes towards the difficulties of English idiom learning, the means and standard deviations for each statement in the sub-scale are displayed in Table 4.

Table 4. Means and standard deviations for EFL college students' attitudes towards the difficulties of English idiom learning

\begin{tabular}{|c|c|c|c|}
\hline No. & Statement & $\%$ Agree & Mean (SD) \\
\hline Q9 & Idioms are difficult & 23.4 & $2.82(0.97)$ \\
\hline Q10 & $\begin{array}{l}\text { Idioms are difficult because they are not frequent and familiar } \\
\text { (frequency and familiarity) }\end{array}$ & 39.0 & $3.10(1.07)$ \\
\hline Q11 & $\begin{array}{l}\text { Idioms are difficult because they are nonliteral (figurative) so the } \\
\text { meaning of the idiom is not the meaning of its constituent words }\end{array}$ & 65.6 & $3.57(1.04)$ \\
\hline Q12 & Idioms are difficult because they are hard to use in contexts & 37.2 & $3.06(1.07)$ \\
\hline Q13 & Idioms are difficult because some do not have L1 equivalents & 62.8 & $3.62(1.06)$ \\
\hline Q14 & $\begin{array}{l}\text { Idioms are difficult because they require cultural and historical } \\
\text { knowledge }\end{array}$ & 50.0 & $3.40(1.03)$ \\
\hline
\end{tabular}

Note: $\mathrm{N}=218 . \%$ Agree $=\%$ of participants choosing agree or strongly agree. $\mathrm{SD}=$ standard deviation

The most surprising finding was that students believed that idioms were not difficult. The percentage of agreement to statement 9 was 23.4\%. The participants believed that idioms were easy for them. Cooper (1999), Cedar (2008) and many others showed that idioms are difficult for many ESL/EFL learners. The participants of the present study seemed to be unaware of the difficulty of idioms. Moreover, only $37.2 \%$ of the participants believed that idioms were hard to use in contexts. Irujo (1986b) pointed out that idioms are hard to use correctly particularly due to 
grammatical constraints. The participants seemed unaware of the difficulty of employing idioms correctly in appropriate situations.

\subsubsection{Comprehension Strategies}

The means and standard deviations for each statement in the third sub-scale are shown in Table 5 . Contextualization was the most common method for learning idioms ( $\mathrm{M}=3.91)$, followed by key words $(\mathrm{M}=3.88$ ), and descriptive definitions in English $(M=3.75)$. L1 $(M=3.10)$ and etymological explanation $(M=3.09)$ were the less common methods for learning idioms. This is consistent with Cooper (1999) who demonstrated that learners most frequently use contextualization as a strategy.

Table 5. Means and standard deviations for EFL college students' attitudes towards the learning strategies of idioms

\begin{tabular}{|c|c|c|c|}
\hline No. & Statement & $\%$ Agree & Mean (SD) \\
\hline Q15 & I rely on L1 to learn idioms i.e. through L1 translation & 42.6 & $3.10(1.19)$ \\
\hline Q16 & $\begin{array}{l}\text { I use contextualization to learn idioms i.e. through contexts } \\
\text { (written, video-graphic etc.) }\end{array}$ & 75.7 & $3.91(0.93)$ \\
\hline Q17 & I use etymological explanation to learn idioms (mnemonic strategy) & 38.1 & $3.09(1.12)$ \\
\hline Q18 & $\begin{array}{l}\text { I use descriptive definitions in English to learn idioms (meaning in } \\
\text { L2) }\end{array}$ & 66.5 & $3.75(0.94)$ \\
\hline Q19 & I use key words to learn idioms & 72.5 & $3.88(0.89)$ \\
\hline
\end{tabular}

Note: $\mathrm{N}=218 . \%$ Agree $=\%$ of participants choosing agree or strongly agree. $\mathrm{SD}=$ standard deviation

\subsection{Second Research Question}

The second research question asked: Do EFL college students' attitudes differ according to age? To answer the second research questions, Wilcoxon ranked-sum tests were used to determine if there was a statistically significant difference in the 1) 3 sub-scales of EFL college students' attitudes towards learning English idioms, and 2) the responses of each individual survey item, between the two age groups.

6.2.1 Results of the 3 sub-scales according to age

The results of the Wilcoxon ranked-sum tests are presented in Table 6.

Table 6. Results of the Wilcoxon ranked-sum tests for the second research question

\begin{tabular}{llll}
\hline & Age & & \\
\hline & Less than 25 $(\mathrm{N}=158)$ & 25 and more $(\mathrm{N}=60)$ & $\mathrm{p}$ \\
Importance & $3.99(0.48)$ & $4.24(0.51)$ & $0.000^{*}$ \\
Difficulties & $3.28(0.70)$ & $3.21(0.84)$ & 0.884 \\
Learning strategies & $3.55(0.61)$ & $3.53(0.54)$ & 0.707 \\
\hline
\end{tabular}

Note: Importance $=$ Attitudes towards importance of English idiom learning, Difficulties $=$ Attitudes towards difficulties of English idiom learning, Learning strategies = Attitudes towards learning strategies of idioms. Numbers in parentheses are standard deviation. $\mathrm{p}=\mathrm{p}$-values based on Wilcoxon ranked-sum tests. $*$ indicates significance.

Participants less than 25 years old had statistically significantly less positive attitudes towards importance of English idiom learning than participants 25 or older $(\mathrm{M}=3.99$ for "less than 25 " and $\mathrm{M}=4.24$ for " 25 and more", $\mathrm{p}=$ $0.000)$.

There was no statistically significant difference in attitudes towards difficulties of idioms $(p=0.884)$ and attitudes towards learning strategies of idioms $(\mathrm{p}=0.707)$ between participants less than 25 years old and participants 25 and more.

6.2.2 Results of the individual survey items according to age

Participants less than 25 years old had agreed statistically significantly less to Q1 (Idioms are very important for English language learners), Q2 (English language learners should have knowledge about idioms), Q3 (English language teachers should teach students idioms), Q7 (Idioms are important because they reflect and represent culture), and Q8 (Idioms are important because they indicate native-like knowledge of the language as they reflect proficiency) than participants 25 or older (For Q1, M = 4.16 for "less than 25 ", $\mathrm{M}=4.40$ for " 25 or more", $\mathrm{p}=0.014$; 
for Q2, $M=4.34$ for "less than 25", $M=4.58$ for "25 or more", $p=0.035$; for $Q 3, M=3.87$ for "less than 25 ", $M=$ 4.18 for "25 or more", $\mathrm{p}=0.010$; for $\mathrm{Q} 7, \mathrm{M}=3.89$ for "less than 25 ", $\mathrm{M}=4.18$ for " 25 or more", $\mathrm{p}=0.036$; for $\mathrm{Q} 8$, $\mathrm{M}=3.89$ for "less than 25 ", $\mathrm{M}=4.35$ for " 25 or more", $\mathrm{p}=0.000$ ).

There was no statistically significant difference in the responses of other survey items among participants with different age groups ( $\mathrm{p}>0.05)$.

\subsection{Third Research Question}

The Third research question asked: Do EFL college students' attitudes differ according to year of study? To answer research questions 3, Kruskal-Wallis tests were used to determine if there was a statistically significant difference in the 1) 3 sub-scales of EFL college students' attitudes towards learning English idioms, and 2) the responses of each individual survey item, among participants with different year of study.

6.3.1 Results of the 3 sub-scales according to year of study

The results of the Kruskal-Wallis tests are presented in Table 7. There was no statistically significant difference in attitudes towards importance of idioms $(\mathrm{p}=0.523)$, attitudes towards difficulties of English idiom learning ( $\mathrm{p}=$ $0.214)$, and attitudes towards learning strategies of idioms $(\mathrm{p}=0.584)$, among participants in different year of study.

Table 7. Results of the Kruskal-Wallis tests for the third research question.

\begin{tabular}{llllll}
\hline \multicolumn{7}{l}{ Year of study } & & & \\
\hline & $2(\mathrm{~N}=8)$ & $3(\mathrm{~N}=44)$ & $4(\mathrm{~N}=91)$ & $5(\mathrm{~N}=38)$ & $\mathrm{p}$ \\
Importance & $3.61(1.02)$ & $4.04(0.37)$ & $4.06(0.47)$ & $4.11(0.57)$ & 0.523 \\
Difficulties & $2.73(0.77)$ & $3.33(0.68)$ & $3.19(0.74)$ & $3.22(0.79)$ & 0.214 \\
Learning strategies & $3.40(0.75)$ & $3.50(0.49)$ & $3.51(0.64)$ & $3.65(0.60)$ & 0.584
\end{tabular}

Note: Importance $=$ Attitudes towards importance of English idiom learning, Difficulties = Attitudes towards difficulties of English idiom learning, Learning strategies = Attitudes towards learning strategies of idioms. Numbers in parentheses are standard deviation. $\mathrm{p}=\mathrm{p}$-values based on Kruskal-Wallis tests. * indicates significance.

6.3.2 Results of the individual survey items according to year of study

There was a statistically significant difference in the responses of Q7 (Idioms are important because they reflect and represent culture) among participants with different year of study $(\mathrm{p}=0.017)$. In particular, the results of the pairwise comparisons indicated that people in $2^{\text {nd }}$ year of study had agreed statistically significantly less to Q7 than people in the $4^{\text {th }}$ year of study $(\mathrm{M}=2.88$ for " 2 ", $\mathrm{M}=4.12$ for " 4 ", $\mathrm{p}=0.013)$; there was no statistically significant difference in responses of Q7 between participants in other years of study ( $p=0.142$ for 2 vs. $3, p=0.076$ for 2 vs. 5 , p = 1.000 for 3 vs. $5, p=0.954$ for 3 vs. $4, p=1.000$ for 4 vs. 5).

There was a statistically significant difference in the responses of Q13 (Idioms are difficult because some do not have L1 equivalents) among participants with different year of study $(\mathrm{p}=0.029)$. However, the results of the pairwise comparisons indicated that there was no statistically significant difference in responses of Q13 among participants in different year of study $(\mathrm{p}=1.000$ for 2 vs. $5 ; \mathrm{p}=1.000$ for 2 vs. $4 ; \mathrm{p}=0.113$ for 2 vs. 3 ; $\mathrm{p}=1.000$ for 4 vs. 5 ; $\mathrm{p}=0.247$ for 3 vs. 5 ; $\mathrm{p}=0.092$ for 3 vs. 4 ). Thus, we concluded that there was no statistically significant difference in responses of Q13 among participants in different year of study.

There was no statistically significant difference in the responses of other survey items among participants with different year of study $(\mathrm{p}>0.05)$.

\subsection{Limitations}

The main limitation of this study is derived from female-only participants. Relying on the perceptions of EFL college students in a single-gender education environment will limit generalization to the opposite gender. Therefor, the effect of gender cannot be examined. Also, the participants came from one local college. Having data from more than one local college would provide more reliable data.

\section{Conclusion and Recommendations}

The study investigated EFL college students' attitudes towards (1) the importance of idiom learning, (2) the difficulties of idiom learning and (3) the learning strategies of idioms. Additionally, the independent variables measured were age and year of study. From the present study, we conclude that Kuwaiti EFL college students had positive attitudes towards idiom learning particularly with respect to the importance of English idioms, the 
difficulties and learning strategies of idioms. The finding showed that students were aware of the importance of idioms and its link to various factors such as frequency, culture and proficiency. One of the unexpected findings was that students assume idioms were easy. The present study uncovered that EFL college students seemed to be unaware of the difficulty of idioms. Moreover, contextualization was the most preferred learning strategy. However, L1 and etymological explanation were less preferred as methods for learning idioms. Additionally, the results indicated significant differences in attitudes towards English idiom learning for the independent variable age.

Based on the results of the present study, EFL instructors are recommended to make EFL college students aware of the difficulty of idiom learning so they can focus on studying them. Also, EFL instructors are encouraged to use contextualization and key words with students since these are the preferred strategies for learning English idioms. The use of L1, Arabic, as a learning strategy should be limited as it can yield to negative transfer and it is less preferred by Kuwaiti EFL college students.

\section{References}

Adkins, P. G. (1968). Teaching idioms and figures of speech to non-native speakers. Modern Language Journal, 52(3), 148-152. https://doi.org/10.1111/j.1540-4781.1968.tb01884.x

Bachman, L. F. (1990). Fundamental considerations in language testing. Oxford: Oxford University Press.

Boers, F., Eyckmans J., \& Demecheleer M. (2004). Cross-cultural variation as a variable in comprehending and remembering figurative idioms. European Journal of English Studies, 8(3), 375-388. https://doi.org/10.1080/1382557042000277449

Boers, F., Demecheleer, M., \& Eyckmans, J. (2004). Etymological elaboration as a strategy for learning idioms. In P. Bogaards \& B. Laufer (Eds.), Vocabulary in a second language: Selection, acquisition, and testing, 53-78. Amsterdam: John Benjamins. https://doi.org/10.1075/1llt.10.07boe

Boers, F., Eyckmans, J., Kappel, J., Stengers, H., \& Demecheleer, M. (2006). Formulaic sequences and perceived oral proficiency: Putting a lexical approach to the test. Language Teaching Research, 10(3), 245-261. https://doi.org/10.1191/13621688061r195oa

Bortfeld, H. (2003). Comprehending idioms cross-linguistically. Experimental Psychology, 50, 217-230. https://doi.org/10.1026//1617-3169.50.3.217

Bulut, T. \& Çelik -Yazici, Y. (2004). Idiom processing in L2: Through rose-colored glassed. The Reading Matrix, 4, 105-116.

Cedar, P. (2008). Learner's recognition of Thai-English idioms counterparts. Linguistic Journal, 3(3), 1-13.

Celce-Murcia, M. (2008). Rethinking the role of communicative competence in language teaching. In E. Alcón Soler \& P. Safont Jordà (Eds.), Intercultural language use and language learning, 41-57. Dordrecht, The Netherlands: Springer.

Chen, B. (2004). A study of L2 color idiom comprehension - Effects of type, proficiency and context. Unpublished MA thesis. Guangdong University of Foreign Studies, China.

Clarke D. F. \& Nation, I. S. P. (1980). Guessing the meanings of words from context: Strategy and techniques. System, 8(3), 211-220. https://doi.org/10.1016/0346-251X(80)90003-2

Cooper, T. C. (1998). Teaching idioms. Foreign Language Annals, 31(2), 255-266. https://doi.org/10.1111/j.1944-9720.1998.tb00572.x

Cooper, T. C. (1999). Processing of idioms by L2 learners of English. TESOL Quarterly, 33(2), 233-262. https://doi.org/10.2307/3587719

Cowie, A. \& Mackin, R. (1975). Oxford dictionary of current idiomatic English. Oxford: Oxford University Press.

Dixon, R. (1994). Essential idioms in English. New Jersey: Prentice Hall Regents.

Dörnyei, Z. \& Csizér, K. (2002). Some dynamics of language attitudes and motivation: Results of a longitudinal national survey. Applied Linguistics, 23, 421-462. https://doi.org/10.1093/applin/23.4.421

Dunn, O. (1964). Multiple comparisons using rank sums. Technometrics, 6, 241-252. https://doi.org/10.1080/00401706.1964.10490181

Elkilic, G. (2008). Turkish students' understanding of transparent and opaque idioms in English in reading as well as speaking. Journal of Language and Linguistic Studies, 4, 27-41. 
Ellis, N. C. (1997). Vocabulary acquisition: Word structure, collocation, word- class, and meaning. In N. Schmitt \& M. McCarthy (Eds.), Vocabulary, description, acquisition and pedagogy, 122-139. Cambridge: Cambridge University Press.

Fakeye, D. (2010). Students' personal variables as correlates of academic achievement in English as a second language in Nigeria. Journal of Social Sciences, 22(3), 205-211. https://doi.org/10.1080/09718923.2010.11892803

Fernando, C. (1996). Idioms and Idiomaticity. Oxford: Oxford University Press.

Foster, P. (2001). Rules and routines: A consideration of their role in the task-based language production of native and non-native speakers. In M. Bygate, P. Skehan, \& M. Swain (Eds.), Researching pedagogic tasks: Second language learning, teaching, and testing, 75-94. Harlow: Longman.

Gardner, R. C., \& Lambert, W. E. (1972). Attitudes and motivation in second language teaching. Rowley, MA: Newbury House.

Gardner, R. C. (1985). Social psychology and second language learning: The role of attitudes and motivation. London, UK: Edward Arnold.

Gibbs, R. W. (1993). Why idioms are not dead metaphors. In C. Cacciari \& P. Tabossi (Eds.), Idioms: Processing, structure, and interpretation, 57-77. New Jersey: Lawrence Erlbaum Associates.

Gibbs, R. W. (1994). The Poetics of mind, figurative thought, language, and understanding. Cambridge: Cambridge University Press.

Glucksberg, S (2001). Understanding Figurative Language. Oxford: Oxford University Press.

Grant, L. E. (2007). In a manner of speaking: Assessing frequent spoken figurative idioms to assist ESL/EFL teachers. System, 35(2), 169-181. https://doi.org/10.1016/j.system.2006.05.004

Guduru, R. (2012). Learning academic idioms: Some useful techniques for beginner learners. Language in India: Strength for Today and Bright Hope for Tomorrow, 12(2), 494-585.

Hollander, M. \& Wolfe, D. (1999). Nonparametric statistical methods. New York: John Wiley and Sons.

Howarth, P. (1998). Phraseology and second language proficiency. Applied Linguistics, 19, $24-44$. https://doi.org/10.1093/applin/19.1.24

Irujo, S. (1986a). Don't put your leg in your mouth: Transfer in the acquisition of idioms in a second language. TESOL Quarterly, 20(2), 287-304. https://doi.org/10.2307/3586545

Irujo, S. (1986b). A piece of cake: Learning and teaching idioms. ELT Journal, 40(3), $236-242$. https://doi.org/10.1093/elt/40.3.236

Kara, A. (2009). The effect of a 'learning theories' unit on students' attitudes towards learning. Australian Journal of Teacher Education, 34(3), 100-113. https://doi.org/10.14221/ajte.2009v34n3.5

Khan, Ö., \& Can Daşkin, N. C. (2014). "You reap what you sow"- idioms in materials designed by EFL teacher-trainees. Novitas-ROYAL (Research on Youth and Language), 8(2), 97-118.

Kövecses, Z. \& Szabo, P. (1996). Idioms: A view from cognitive linguistics. Applied Linguistics, 17(3), 326-355. https://doi.org/10.1093/applin/17.3.326

Lattey, E. (1986). Pragmatic classification of idioms as an aid for the language learner. International Review of Applied Linguistics, 24(3), 217-233. https://doi.org/10.1515/iral.1986.24.1-4.217

Lazar, G. (1996). Using figurative language to expand students' vocabulary. ELT Journal, 50, 43-51. https://doi.org/10.1093/elt/50.1.43

Littlemore, J., \& Low, G. (2006). Metaphoric competence, second language learning, and communicative language ability. Applied Linguistics, 27(2), 268-294. https://doi.org/10.1093/applin/aml004

Liu, D. (2008). Idioms: Descriptions, comprehension, acquisition, and pedagogy. New York: Routledge.

Lundblom, E., \& Woods, J. (2012). Working in classroom: Improving idiom comprehension through class wide peer tutoring. Communication Disorder Quarterly, 33, 202-219. https://doi.org/10.1177/1525740111404927

Makkai, A. (1978). Idiom structure in English. The Hague: Mouton.

Moon, R. (1998). Fixed expressions and idioms in English: A corpus-based approach. New York: Oxford University 
Press.

Nation, P. \& Meara, P. (2002). Vocabulary. In N. Schmitt (Ed.), An introduction to applied linguistics, 35-54. London: Arnold.

Nattinger, J. \& DeCarrico J. (1992). Lexical Phrases and Language Teaching. Oxford: Oxford University Press.

Nippold, M. A. \& Fey, S. H. (1983). Metaphoric understanding in preadolescents having a history of language acquisition difficulties. Language, Speech, and Hearing Services in Schools, 14, 171-180. https://doi.org/10.1044/0161-1461.1403.171

Nippold, M. A. (1991). Evaluating and enhancing idiom comprehension in language-disordered students. Language, Speech, and Hearing Services in Schools, 22, 100-106. https://doi.org/10.1044/0161-1461.2203.100

Ohlrogge, A. (2009). Formulaic expressions in intermediate EFL writing assessment. In R. Corrigan, E. A. Moravcsik, H. Ouali \& K. M. Wheatley (Eds.), Formulaic language: Acquisition, loss, psychological reality, and functional explanations, 375-386. Philadelphia: John Benjamins.

Oller, J.W. (1979). Language Tests at School. London: Longman.

Pimenova, N. (2011). Idioms comprehension strategies used by English and Russian language learners in a think-aloud study (Unpublished doctoral dissertation). Purdue University, West Lafayette, Indiana.

Richards, J. C. (1996). Reflections on language teaching: Idiomatically speaking. Zielsprache Englisch, 26(3), 32-3.

Saleh, N., \& Zakaria, N. (2013). Investigating the difficulties faced in understanding, and strategies used in processing English idiom by the Libyan students. International Journal of English Language and Translation Studies, 1(2), 69-90.

Schmitt, N. (2000). Vocabulary in Language Teaching. Cambridge: Cambridge University Press.

Seidl, J., \& McMordie, W. (1978). English idioms and how to use them. Oxford: Oxford University Press.

Simpson, R. \& Mendis, D. (2003). A corpus-based study of idioms in academic speech. TESOL Quarterly, 37(3), 419-442. https://doi.org/10.2307/3588398

Sparado, K. (2013). Maturational constraints on lexical acquisition in a second language. In G. Granena and M. Long (Eds.), Sensitive periods, language aptitude, and ultimate L2 attainment, 43-68. Amsterdam: John Benjamins.

Szczepaniak, R., \& Lew, R. (2011). The role of imagery in dictionaries of idioms. Applied Linguistics, 32(3), 323-347. https://doi.org/10.1093/applin/amr001

Tărcăoanu, M. C. (2012). Teaching and learning idioms in English (theoretical and practical considerations). Scientific Journal of Humanistic Studies, 220-228.

Thiel, F. (1979). The case for idioms. Die Unterrichtspraxis, 12, 21-24. https://doi.org/10.2307/3529399

Tran, T. (2011). Using ready-made materials for teaching idioms. Papers presented at the 41th Annual New York State TESOL Conference. Melville, New York, USA.

Wray, A. (2000). Formulaic sequences in second language teaching: Principle and practice. Applied Linguistics, 21(3), 463-489. https://doi.org/10.1093/applin/21.4.463

Wray, A. (2002). Formulaic language and the lexicon. Cambridge: Cambridge University Press. https://doi.org/10.1017/CBO9780511519772

Zuo H. (2008). Comprehension of unfamiliar English idioms by Chinese EFL learners in reading. CELEA Journal, $31(3), 9-29$.

Zyzik E. (2009). Teaching and learning idioms: The big picture. CLEAR News, 13(2), 1-8. 